\title{
Recognition of relational strategy content: insight from the managers' view
}

\author{
Agnieszka Zakrzewska-Bielawska ${ }^{1}$
}

Received: 8 December 2017 / Revised: 4 May 2018 / Accepted: 8 May 2018 /

Published online: 21 May 2018

(C) The Author(s) 2018

\begin{abstract}
The paper aims to recognize how managers perceive a firm's relational strategy content by identification of strategic choices made within it. The paper presents theoretical assumptions of the relational view of strategy based on identified fundamental strategic choices that form the content of relational strategy, presents hypotheses that link this content with the relational view of a firm, as well as 'enterprise logic', understood as the way in which top managers conceptualize their firm and its relationships with stakeholders. The research was conducted in 53 companies based in Poland using semi-structured interviews with executives. Both content and statistical analyses are to be used. The research results made it possible to discern key strategic choices that make up the content of relational strategy. These, in the opinion of managers, should include choices regarding the process of creating and appropriating value, selecting a partner and their significance, and the associated interorganizational dynamics as well as the way of forming interorganizational relationships.
\end{abstract}

Keywords Relational view $\cdot$ Strategy $\cdot$ Interorganizational relations $\cdot$ Value creation and appropriation $\cdot$ Partners

\section{JEL Classification $\quad \mathrm{L} 14 \cdot \mathrm{L} 21$}

Agnieszka Zakrzewska-Bielawska

agnieszka.zakrzewska-bielawska@p.lodz.pl

1 Department of Management, Lodz University of Technology, ul. Piotrkowska 266, 90-924 Lodz, Poland 


\section{Introduction}

The approach to strategy evolved along with the development of strategic management (Furrer et al. 2008; Guerras-Martín et al. 2014) and the emergence of new schools of strategy (Mintzberg et al. 2009). This was a result of the acceptance of various epistemological, axiological and methodological assumptions (Ronda-Pupo and Guerras-Martin 2008; Vargas-Hernández 2014). In recent years, strategic issues were dominated by the resource-based view (RBV) (Barney and Clark 2007; Barney et al. 2011), as influenced by a turbulent and less and less predictable environment. What was particularly appreciated was the significance of non-material resources, including knowledge and dynamic abilities, as well as interorganizational relations. In particular, interorganizational relations have become a strategic resource (i.e. scarce, valuable, difficult to imitate or substitute) linking the remaining resources with opportunities appearing on the market. As a consequence, aside from competition for products and markets, which was characteristic for the first school of strategy (e.g. planning, positioning) (Mintzberg et al. 2009) as well as resources and competences, which characterize the resource approach (Barney and Clark 2007; Eisenhardt and Martin 2000), the third pillar in the theory of strategy is competition for value from relationships (Contractor and Beldona 2002; Venkatraman and Subramaniam 2002). Collaborating businesses, cooperating and coopetiting, create value which can then further be subject to appropriation.

Building competitive advantage based on the value of relations became the core of the relational view of strategy (Dyer and Singh 1998; Lavie 2006). The main explanations of this rested on a foundation of resource-based theory, but also referred to industrial marketing theory, transactional cost theory, supply chain management theory, stakeholder theory, game theory or network theory, which has been explored in recent years (Moliterno and Mahony 2011; Brandenburger and Nalebuff 2011; Ackermann and Eden 2011; Tangpong et al. 2015). According to these theories, interorganizational relations were analyzed in terms of various motives, including those of establishing relations, i.e., the creation and appropriation of value (e.g. Wagner et al. 2010; Haas et al. 2012), the development of competitive advantage (e.g. Dyer and Singh 1998; Lavie 2006; Kobayashi 2014), obtaining economic rent (e.g. Castaldo 2007; Gürtler 2010), access to resources (e.g. Jap 2001; Hardy et al. 2003; Baraldi et al. 2012), flexibility (Martínez-Sánchez et al. 2009), learning (Mariotti 2012), innovativeness (e.g. Thorgren et al. 2009; Najafian and Colabi 2014), or coordination of partners' activities (Danese et al. 2004; Vlaar et al. 2007). However, despite the high intensity of research in the area of interorganizational relations, there is still a deficit of research into relational strategy, the content of which has not yet been precisely determined, either on an ontological or epistemological basis. Ontology and epistemology are both important elements of the philosophy of knowledge. Even if they often overlap, they remain distinct: epistemology is about the way we know things, whereas ontology is about what things are (Johnson and Duberley 2000; Grix 2004). In this sense, at the ontological level, the actual existence 
of a relational strategy of a firm is considered and its fundamental elements are indicated, whereas at the epistemological level, I have chosen the approach of a relational view as the perspective for their identification. It should be pointed out here that meaning and managers' thoughts are not objective but rather subjective entities, and thus should be understood through careful qualitative investigation and analysis.

From a strategic perspective, the relational view (RV) indicates that interfirm cooperation in dyads and relational networks allows firms to specialize in core businesses, to outsource value-chain stages, to act more quickly than rivals, and finally to achieve a sustained competitive advantage (Wong 2011), but what components the relational strategy consists of is unknown. For this reason, the core research question of this study is what constitutes the relational strategy and what strategic choices are made by managers within it. These strategic choices together constitute the content of the relational strategy.

The answer to this question makes it possible to fill the research gap related to the epistemological basis of an enterprise's strategy considered from relational view perspective. Therefore, the goal of this paper is to identify the content of relational strategy by the strategic choices made, in the context of the relational view of a firm. It will be based on the results of research conducted using interviews with executives in 53 companies operating in Poland. I have adopted an interpretive approach (Porac et al. 1989), which offers an explanation for how managers perceive the role and significance of interorganizational relations in building a firm's competitive advantage, how managers conceptualize their business from a relational perspective, and how managers identify the content of their relational strategy through the lens of the strategic choices they have made.

In the literature on strategic management, the concept of "choice" is of a dual nature and can be understood in both a broad and in a strict sense (UrbanowskaSojkin 2017). In the broad sense, strategic choice refers to the set of actions that make it possible to identify a particular variant (among acceptable strategic options), which given the current state of knowledge and conditions (criteria) of the choice, are to be implemented next. This approach thus emphasizes the aspect of active decision making, indicating the strategic options that can possibly be implemented. In the strict sense, strategic choice is perceived as the result of choice and denotes a strategic decision that is the result of a process of comparative analysis of strategic options, considering the aims and criteria outlined by the decision-makers, and that causes particular, long-lasting material, financial, and organizational consequences for the firm (Urbanowska-Sojkin 2017). In this article, strategic choices will be analyzed from the perspective of choice in the broad sense.

This paper contributes to the literature on strategic management by recognizing how managers perceive a firm's relational strategy, in particular (1) what significance do they attribute to interorganizational relations in building competitive advantage, (2) how do they define a firm's relational strategy, and (3) what elements should it contain, in the context of strategic choices in the broad sense?

The structure of the paper is as follows. First, I discuss the relational view (RV) approach to firms' strategies and determine basic strategic choices related to it. Second, I present the results of the content analysis from in-depth interviews, the 
research model, and results of statistical analysis. I close with limitations of the research and directions for further research.

\section{Theoretical background of the relational view of firms' strategy}

The relational view posits that firms are able to develop key relationships as relational assets to achieve competitive advantage (Dyer and Singh 1998). For this reason, the relational view of strategy is frequently perceived as a development of the resource-based view, indicating that interorganizational relations constitute a company's strategic, idiosyncratic and invisible resources (Arya and Lin 2007; Wong 2011). On the other hand, however, the relational view also links the evolutionary view and the associated business ecosystem, (Iansiti and Levien 2004), indicating that organizations are not atomistic entities, but are anchored in dyads and network relations (Yang et al. 2011; Li et al. 2017), which can be shaped emergently, taking into consideration the mechanisms of self-organization.

Many studies (e.g. Donaldson and O'Toole 2007; Baum et al. 2014) have shown that interorganizational relations constitute the basis for strategic actions by contemporary companies that want to collaborate with other parties in order to gain additional economic rents, which are called relational rents. (Dyer and Singh 1998; Kobayashi 2014). The relational rent is defined as a supernormal profit generated from the joint efforts of partners that invest in relation-specific assets, share knowledge, combine complementary resources and use effective governance mechanisms (Dyer and Singh 1998). Seeking relational rents is thus the main motivation for creating interorganizational relations systems, at the same time determining the relational view of a firm. This view is expressed in a firm's relational orientation, which is a kind of strategic orientation. Scholars commonly define strategic orientation as the principles underlying the activities, processes, and strategic directions that a firm undertakes to create behaviors necessary for achieving superior performance (Gatignon and Xuereb 1997). Strategic orientation is the business philosophy and reflects a firm's perspective on how to conduct business (Mu et al. 2017). From this point of view, the relational orientation as the strategic orientation of the firm is defined as the extent to which firms emphasize developing and maintaining relationships with customers, suppliers, competitors and other partners that result in mutual exchange and benefits (Panayides 2007; Ho et al. 2016). This orientation is expressed not only in the formation and development of many diverse relationships with individual parties in the environment (Lavie 2006), but also in the knowledge of the mutual expectations of the partners, clearly defined goals of the cooperation, the meeting of reciprocal needs (Ritala and Ellonen 2010), as well as conscious management of interorganizational relations (Gulati 1998; Child et al. 2005) through the use of various dedicated tools (e.g., CRM, SCM). The expectations of collaboration partners should be taken into account in a firm's strategy so as to effectively build and manage a portfolio of heterogeneous relations (Hoffmann 2007).

For the relational orientation of the firm, an important factor is the attitude of managers to building competitive advantage based on value from relations. The way in which top managers conceptualize their firm and its relationships with 
stakeholders in an environment is what Crilly and Sloan (2012) define as 'enterprise logic'. Using the stakeholders and dominant theories of logic, they distinguish three types of logic: firm-centric, industry network, and extended enterprise. The first concerns value capture. Interorganizational relations are not numerous and are characterized by the relative independence of the parties (transactionality). The second type of logic focuses on economic value creation through relational rents. The underlying strategic intent is to use collaboration with market stakeholders to create value and, in doing so, to gain competitive advantage, reputation, and a capacity for innovation. Interorganizational relations are relatively dense (they are numerous and are formed with diverse partners) and have a transactional-relational nature. The third type is related to value creation not only for the firm, but also for other actors in society. Interorganizational relations are numerous and diverse (dense network of relations) and have the relational character (based on trust). This 'enterprise logic' plays a role in determining the variety of stakeholders that a firm attends to. Specifically, 'enterprise logic' may constrain or facilitate a firm's capacities to deal with a variety of market partners and to attend to multiple partners simultaneously. Thus, it should influence the relational orientation of the firm. This is why I propose the following hypothesis:

\section{H1: Enterprise logic affects a firm's relational orientation}

The 'enterprise logic' explains why some managers perceive relationships with market partners as involving risk, conflict and trade-offs, while others see opportunity, interdependence, and mutual benefits. The more extended and more open the enterprise logic is, where managers have a higher degree of autonomy to create a virtuous cycle of attention to market partners, the stronger the firm's relational orientation should be, as evident not only in the quantity and diversity of interorganizational contacts made and being developed, but also in considering partners' expectations, which leads to benefits for both sides (Post et al. 2002). In this case, firms are more likely to be comfortable with a measure of risk taking, seizing opportunities, and innovating in their relations in ways that lead to new business models that reinforce both social and economic performance (Porter and Kramer 2006). On the other hand, the more transactional the enterprise logic is (firm-centric logic), the weaker the relational orientation of the firm will be. Managers concentrate on threat management and are less likely to pursue novel approaches to dealing with their market partners (Crilly and Sloan 2012), and less often take into account their partners' expectations in their firm's strategy.

In accordance with the relational view, companies should build and develop such interorganizational relations that allow them to obtain clear benefits and at the same time limit the risk of not obtaining a relational rent. The question that arises from this is how to do that? And here, the answer is relational strategy. In the literature, relational strategy has not yet been unambiguously defined. The Strategor Group (STRATEGOR 1997) defines relational strategy as one in which the existence of privileged relations established by a company with selected partners in its environment is a foreground element and competition a background element. Other researchers do not offer an unambiguous definition of relational strategy as such, but rather refer to specific relations and describe them on their 
particular continuums (De Wit and Meyer 2005), or they define relational strategy referring to particular subjects in a relationship or its nature, e.g. supply chain relational strategy (Iyer et al. 2014), cooperative strategy (Child et al. 2005), or coopetition strategy (Chin et al. 2008). However, such an approach seems insufficient, as interorganizational relations can be established with various partners (suppliers, customers, competitors, complementors), and the relational strategy should take their value-creating heterogeneous portfolio into account, focusing not only on individual relations, but also on their interdependence. Hence, taking into account the assumptions of the relational view approach, I define the relational strategy as a holistic concept of actions that covers strategic choices about the establishment of, development, and withdrawal from interorganizational relations with different partners. These occur in conditions of uncertainty (restrictions, pressures and opportunities) with the aims of generating value and appropriating it, of maintaining an organization's potential for growth, and receiving a relational rent.

However, here an issue appears. What is the content of the relational strategy, in the context of strategic choices, to allow it to be formed efficiently and to achieve the intended benefits from its implementation. As an attempt to answer this question, a conceptual model was adopted from Zakrzewska-Bielawska (2017), taking into account the strategic choices essential for the relational strategy of an enterprise. This model is presented in Fig. 1.

The first strategic choice is creating and appropriating value through the shaping, maintaining and developing of interorganizational relations. This is the goal of relational strategy and one of the fundamental problems of contemporary strategic management (Coff 2010). The management team must make its own strategic choice regarding the logic of value creation as well as the mechanism for appropriating it. In the first case, a choice can be made between the logic of a value chain (Hammervoll 2009), according to which forming and maintaining relations is of a transactional character, and the logic of a value network (Peppard and Rylander 2006; Ritala and Ellonen 2010), according to which the collaboration of businesses, clients (consumers), suppliers, complementors and competitors provides benefits to each of these (Stabell and Fjeldstad 1998). Regarding appropriating value, strategists make a choice between mechanisms for protecting value and mechanisms for maximizing value (Ellegaard et al. 2014). Firms should strive for balance between creating and appropriating value, whereby creating value is more important and more difficult (Di Gregorio 2013).

Fig. 1 Four strategic choices within a firm's relational strategy-conceptual model Source: based on Zakrzewska-Bielawska (2017)

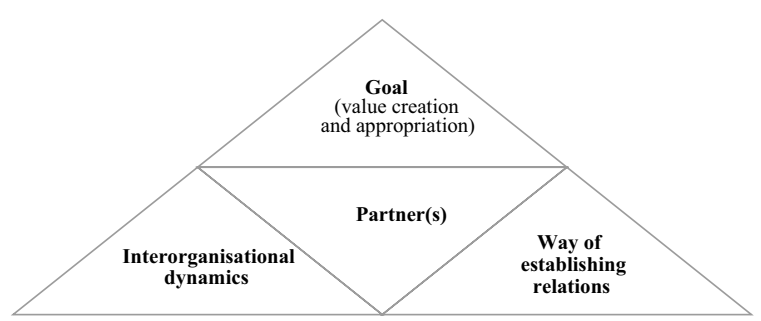


Interorganizational relations may be established with a variety of partners. These may include suppliers, customers, competitors, R\&D firms, financial firms, public institutions, and others. We can divide these partners into competitive (competitors) and non-competitive (other) partners. Thus, the choice of an appropriate partner is the next strategic choice, as on the one hand, they determine the efficiency and stability of long-term cooperation (Feng et al. 2010), and on the other, if the partner is not right, they may destabilize the interorganizational cooperation process. From the relational view perspective, there are some factors determining the proper choice of a partner, such as: (1) partners' technological alignment (i.e., technical capability, resource complementarity, and overlapping knowledge bases), (2) partners' strategic alignment (i.e., motivation correspondence and goal correspondence), and (3) partners' relational alignment (i.e., compatible cultures, propensity to change, longterm orientation) (Emden et al. 2006). Trust is also an important factor, because it reduces the uncertainty that accompanies mutual relations based on the subjectively assessed probability regarding behaviors and actions taken by the other party (Jiang et al. 2015; Ashnai et al. 2016). Total trust is rather rare. People usually partly trust their partners, but also partly do not trust them (Welch 2006). Therefore, it is necessary to assume the existence of distrust (as the opposite of trust) in interorganizational relations.

The choice of a partner determines the next strategic choice, which has to do with interorganizational dynamics. Bengtsson and Kock (1999) distinguished four types of cross-organizational dynamics, such as coexistence, competition, cooperation and coopetition. In the relational view, the fundamental source of competitive advantage is regarded as the cooperation of partners (Dyer and Singh 1998). As a result, relational strategy should, depending on the choice of partner, concentrate on cooperation (with non-competitive partners) and coopetition (with competitive partners) as interorganizational behaviors. Many studies (e.g. Hardy et al. 2003; Fawcett et al. 2014; Zakrzewska-Bielawska 2014) have shown that cooperation and coopetition produce better collective and individual results and allow companies to gain competitive advantage.

Interorganizational relations may be established in a premeditated, previously planned and arranged way, or emerge in the course of operations as a result of opportunities identified and taken, which corresponds to the formation of deliberate or emergent strategies (Mintzberg and Waters 1985). For this reason, the way interorganizational relations are established seems to be the fourth important strategic choice within the content of relational strategy. Due to the purposefulness of choosing a portfolio of relations, relational strategy should be shaped deliberately, but this does not mean, however, that the emergent approach cannot be applied here. Interorganizational relations are also formed through spontaneous acts and without certain previously articulated intentions (Hsieh et al. 2012). Managers are consequently assigned the task to react and respond to unintended opportunities and challenges arising in interorganizational interactions. Therefore, relational strategy is often a result of interactions of deliberate and emergent ways of establishing interorganizational relations.

These four strategic choices are not made in isolation, but are closely connected to one another and are interdependent, creating a portfolio of interorganizational 
relations that allows the enterprise to achieve benefits resulting from collaboration and to obtain the relational rent. Consequently, I propose the second hypothesis.

$\mathrm{H} 2$ : The content of a relational strategy consists in the choices concerning:

(a) the way value is created and appropriated, (b) the partner, (c) the interorganizational dynamics, and (d) the way relations are established

The definition of relational strategy adopted as well as the assumptions regarding its content are closely linked with the relational orientation of a firm. The relational orientation, as mentioned above, is expressed by a conscious orientation toward forming and developing interorganizational relations with the goal of obtaining particular benefits (Lavie 2006; Ho et al. 2016). At the same time, a relational orientation determines the portfolio of a firm's interorganizational relations, their dynamic configuration, and the way in which they are managed (Panayides 2007; Ritala and Ellonen 2010). One may thus presume that the stronger the relational orientation is, as expressed in the number of interorganizational relations and their diversity, in knowledge of the expectations and needs of partners, taking these into account in strategy and satisfying these through actions taken, the greater then the content of the relational strategy should take into account choices that determine key partners for the firm, the manner in which common value is created and appropriated, the interorganizational dynamics as well as the approach to creating, developing and withdrawing from particular relations. Therefore, I propose the following hypothesis:

H3: There is a positive dependence between the relational orientation of a firm and elements of the relational strategy that express its content

Based on the assumptions of the relational view and the relational orientation of the firm, as well as the "enterprise logic", and strategic choices essential for the relational strategy, I built a research model as shown in Fig. 2. In order to test these hypotheses, research was conducted in Polish companies in 2016.

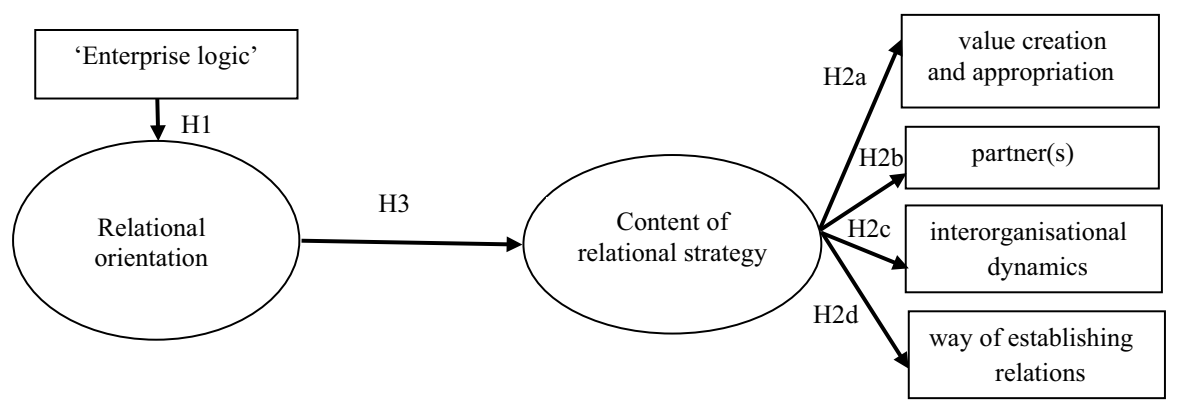

Fig. 2 Research model 


\section{Methodology}

The research included 53 medium-sized companies (i.e. with 50-249 employees), from which a selection was made of 21 firms employing 50-70 people, and 32 firms employing 71-249 people, of which at least 16 employ over 200 individuals. The choice of medium-sized companies for the research was intentional, as this group of firms is characterized by the greatest diversity, which means that it includes some with the traits of small firms as well as those which come closer to those of large companies. The choice of companies for the particular groups was a probabilistic layered random selection (Groves et al. 2011). The frame was the Polish REGON (National Business Registry) database.

I used semi-structured interviews to collect data on managers' perceptions. I conducted 49 interviews with top managers and four interviews with owners. My focus on top management is justified by their importance in shaping 'enterprise logic' (Crilly and Sloan, 2012) and responsibility for the creation and implementation of relational strategy. The interviews took place in the offices of the respondent's company and were preceded by a telephone conversation during which the respondent expressed agreement to give an interview and set the date for the meeting. A meeting lasted on average $30 \mathrm{~min}$. All interviews were recorded (with the respondent's consent) and transcribed, which facilitated subsequent analysis of the material obtained.

In order to achieve the study's objective, I used both content and statistical analysis. The first type was used in order to recognize the significance of interorganizational relations in building competitive advantage and the essence of the relational strategy of the firm. For this reason, I asked respondents two openended questions. I used here NVivo software and conducted a summative content analysis (Hsieh and Shannon 2005) including grouped significant answer excerpts or word clouds.

Statistical analysis was used for testing the hypotheses, with the use of explanatory factor analysis (EFA) and correlations. There are three basic constructs: relational orientation, relational strategy, and 'enterprise logic'. Based on theory and relevant research findings from open-ended questions, I proposed a six-item scale measuring the relational strategic orientation of the firm including the number and variety of partners, their expectations and the needs that a company's vision/ mission and strategy should include. Each item was measured using a seven-point Likert scale, with anchors ranging from strongly disagree (1) to strongly agree (7). Similarly, based on the conceptual model (Fig. 1), four items were measured using a seven-point Likert scale to assess strategic choices within the relational strategy. Respondents were asked to what extent they agree (or disagree) with the idea that relational strategy should consist of strategic choices such as (a) key partners and the strength of their influence, (b) the way of creating/appropriating value (derived benefits), (c) the interorganizational dynamics, and (d) the approach to creating, developing and withdrawing from interorganizational relationships. Because of the use of a Likert scale, the items measured respondents' perceptions rather than measuring objective facts. I analyzed the reliability of the 
scales using Cronbach's alpha, and its validity using Average Variance Extracted (AVE). To assess the 'enterprise logic', I used the self-typing paragraph approach (Doty et al. 1993), asking respondents to identify which of the three logic descriptions, (a) firm-centric, (b) industry network, and (c) extended enterprise (Crilly and Sloan 2012), best describes their firms. It should be pointed out that before asking the closed questions, I explained to the respondents the basic assumptions of the relational view approach and the associated basic concepts that take into account among other things the process of creating and appropriating value, obtaining a relational rent as a result of cooperation, or the concept of interorganizational dynamics.

Because I collected data from managers using a single interview, any relationships observed may be susceptible to common method bias. I followed the procedures recommended by Podsakoff et al. (2003) for limiting the potential for common method variance. Specifically, I assured respondents that there were no right or wrong answers, encouraged them to respond as honestly as possible, grouped construct items in sections and not in variables, and employed multi-response formats.

\section{Findings}

The respondents were first given open-ended questions, which asked them how they perceive the role and significance of interorganizational relations compared to other resources in building competitive advantage, as well as how they define relational strategy and its elements. The answers given were varied, but the clear majority of managers indicated that interorganizational relations (especially with clients and suppliers) are very important to meeting the company's goals, building its image, and the functioning and development of the firm, whereby some of the respondents believe that they should be regarded as equal to other resources. Next, relational strategy should in the respondents' opinion describe when to form and when to withdraw from a particular interorganizational relations with regard to the established goals and benefits that a company expects to gain relative to the expenditures incurred. Just as frequently, they indicated as well that key here is the choice of partners and their division into the "more and less important" parties, depending on the level of trust, the credibility of the partner, or the closeness of the relationship, pointing to the need to determine the interorganizational dynamics. The answers received were subjected to close analysis using NVivo software. Grouped representative samples of respondents' statements as well as word clouds are shown in Fig. 3.

The results confirm that a company's relational strategy is focused on choices regarding the goal of relations (creating and appropriating value), the selection of a partner or partners, as well as interorganizational behavior. The way relationships are formed was indicated indirectly. Most respondents assumed that interorganizational relations should be created deliberately, and only in individual cases was their emergent nature indicated, as evidenced by the following statements:

- "(...) it is a strategy that arises on the run, in the course of learning and adapting to existing conditions (...)"; 


\begin{tabular}{|c|c|}
\hline $\begin{array}{l}\text { Significance of interorganisational relations in } \\
\text { building a firm's competitive advantage }\end{array}$ & Essence of relational strategy in managers' opinions \\
\hline 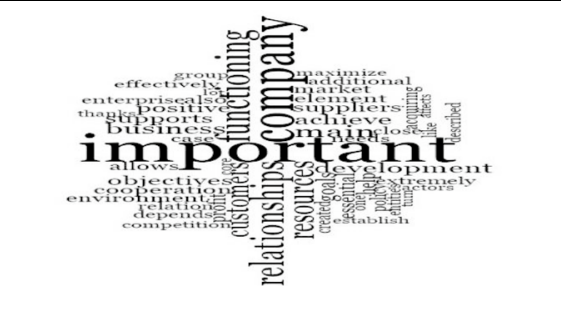 & 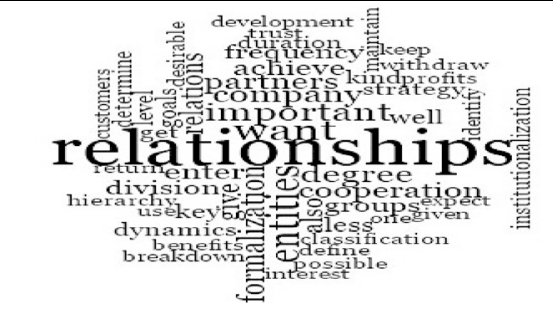 \\
\hline $\begin{array}{l}\text { Sample statements: } \\
\text { "(...) are important in relation to the competition, } \\
\text { they have an influence on the firm's competitive } \\
\text { advantage" } \\
\text { "(...) are an asset that supports profit maximisation" } \\
\text { "(..) are relevant, and their institutionalisation } \\
\text { should be part of the firm's policy or strategy" } \\
\text { "(...) thanks to them, we have an impact on other } \\
\text { assets" } \\
\text { "(...) they allow a business to endure and develop" }\end{array}$ & $\begin{array}{l}\text { Sample statements: } \\
\text { "How to establish relationships, (...), what we want } \\
\text { to achieve and possibly what costs we have to bear" } \\
\text { "(..) how to maintain relations, what we want to } \\
\text { achieve, and what we can devote to these relations" } \\
\text { "(...) which partners are desirable, and which are kept } \\
\text { at a distance" } \\
\text { "(...) Plan with whom you want to enter } \\
\text { relationships, classify and rank in hierarchical groups } \\
\text { so that you know who is important. The degree of } \\
\text { institutionalization of relationships, as well as their } \\
\text { frequency and dynamism" }\end{array}$ \\
\hline
\end{tabular}

Fig. 3 Word clouds and samples of managers' statements

- "Description of the striving to obtain the maximum profit from particular types of relationships, how they are functioning is a spontaneous matter".

In order to clarify the strategic choices that make up the content of relational strategy, as well as to test the advanced hypotheses, respondents were asked to indicate their 'enterprise logic' as well as their relational orientation by responding to particular factors that determine it (OF1-OF6) and to express their opinion regarding which strategic choices (SC1-SC4) should be an element of relational strategy. The research model (Fig. 2) was tested on the basis of the data obtained.

First, I conducted an exploratory factor analysis (EFA) on the scale items of relational orientation by principal component analysis rotated with varimax rotation. From this extraction, I obtained two components. The first can be described as 'partners of relations' (PR) and this includes factors (OF1 and OF2), whereas the second is described as 'partners' expectations' (PE) and includes factors (from OF3 to OF6). In Table 1, I present the EFA results, showing that all items have loadings greater than 0.7 on their factors, with no substantial cross-loadings. The cumulative variance of these two components in rotation sum of squared loadings is $67.50 \%$, of which the Eigenvalue is higher than 1 . The factor loadings are also significantly above the requisite 0.50 , which is much higher than the 0.4 level suggested by Fornell and Larcker (1981), indicating convergent validity for each construct, as each item shared more variance within its construct than with the error variance (Gefen et al. 2000). In addition, the values for Average Variance Extracted (AVE) exceeded the threshold value 0.5 (Chin 1998) that confirms the validity of the scale. 


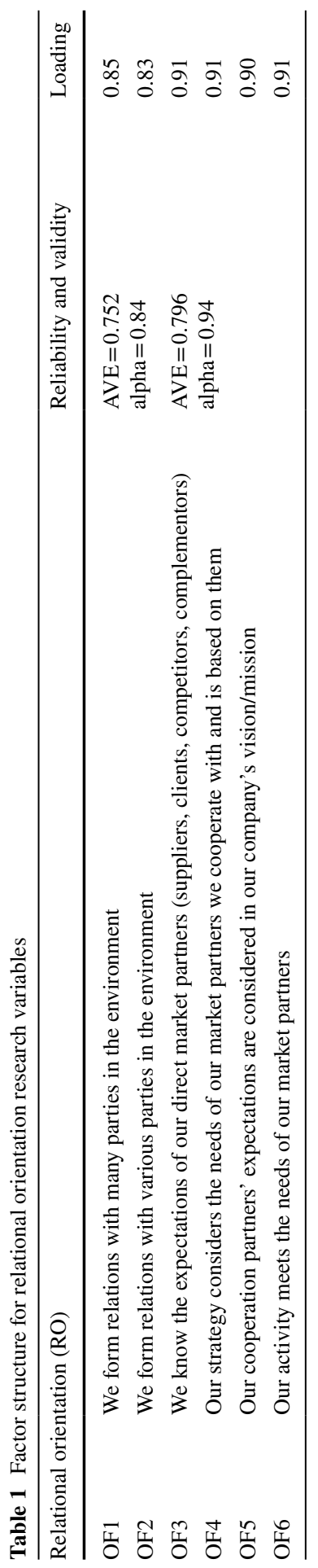


Table 2 Descriptive statistics and correlations of relational orientation components

\begin{tabular}{llllllllll}
\hline Variables of RO & $\bar{x}$ & $\mathrm{SD}$ & $\mathrm{M}$ & $\mathrm{IQR}$ & $\mathrm{OF} 1$ & $\mathrm{OF} 2$ & $\mathrm{OF} 3$ & OF4 & OF5 \\
\hline OF1 & 5.41 & 1.31 & 6 & 1 & & & & & \\
OF2 & 5.28 & 1.29 & 6 & 1 & $0.77^{*}$ & & & & \\
OF3 & 4.91 & 1.14 & 5 & 2 & 0.14 & 0.24 & & & \\
OF4 & 4.83 & 1.08 & 5 & 2 & 0.22 & $0.28^{*}$ & $0.79^{*}$ & & \\
OF5 & 4.81 & 1.03 & 5 & 1 & 0.18 & 0.20 & $0.81^{*}$ & $0.91^{*}$ & \\
OF6 & 4.92 & 1.02 & 5 & 2 & 0.13 & $0.31^{*}$ & $0.79^{*}$ & $0.78^{*}$ & $0.78^{*}$ \\
\hline
\end{tabular}

*Correlation is statistically significant for $p<0.05$

$\mathrm{R} \geq 0.28$ is essential with min. $\mathrm{p}<0.05$

$\bar{x}$ mean, $S D$ standard deviation, $M$ median, $I Q R$ interquartile range

Descriptive statistics as well as the correlation between variables of relational orientation are presented in Table 2. Some of them are high and positively correlated, especially within the particular components, such as 'partners of relations' (PR) and partners' expectations' (PE).

In evaluating 'enterprise logic', managers were asked to indicate which one of three descriptions best describes their firms. The most frequently indicated enterprise logics were industry network (41.5\% of firms), and extended enterprise (51\%), which means that most companies are aware of the benefits obtained from interorganizational relations through value creation not only for the firm, but also for other market partners. Only $7.5 \%$ of studied companies declared firm-centric logic that is characterized by the relative independence of the partners and is transactional in nature.

In order to verify Hypothesis 1, a Kruskal-Wallis test was performed. The results (Table 3) show that the hypothesis cannot be confirmed, because the relationships between 'partners of relations' and type of 'enterprise logic' as well as between 'partners' expectations' and type of 'enterprise logic' were statistically insignificant $(\mathrm{p}>0.05)$. Therefore, the 'enterprise logic' is not positively related to a firm's relational orientation.

Table 3 'Enterprise logic' and relational orientation-Kruskal-Wallis tests

\begin{tabular}{lllll}
\hline Relation orientation (RO) & \multicolumn{2}{l}{ 'Enterprise logic' } & Statistics \\
\cline { 2 - 5 } & $\begin{array}{l}\text { Firm-centric } \\
\text { (average } \\
\text { ranks) }\end{array}$ & $\begin{array}{l}\text { Industry network } \\
\text { (average ranks) }\end{array}$ & $\begin{array}{l}\text { Extended enter- } \\
\text { prise (average } \\
\text { ranks) }\end{array}$ & \\
\hline 'Partners of relations' (PR) & 4.75 & 19.9 & 36.07 & $\begin{array}{l}\mathrm{p}=0.08 \\
\text { Chi square }=5.06 \\
\mathrm{df}=2 \\
\mathrm{p}=0.60 \\
\text { Chi square }=1.01 \\
\mathrm{df}=2\end{array}$ \\
\hline
\end{tabular}


Table 4 Factor structure for relational strategy research variables

\begin{tabular}{llll}
\hline Relational strategy (RS) & Reliability and validity & Loading \\
\hline SC1 & Key partners and the strength of their influence & AVE $=0.688$ & 0.80 \\
SC2 & Way of creating/appropriating value (derived benefits) & alpha $=0.83$ & 0.73 \\
SC3 & Interorganizational dynamics & & 0.85 \\
SC4 & $\begin{array}{l}\text { Approach to creating, developing and withdrawing from } \\
\text { interorganizational relationships }\end{array}$ & 0.91 \\
\hline
\end{tabular}

In the next step, I conducted an exploratory factor analysis (EFA) again, this time on the scale items of relational strategy. Similarly, the principal component analysis rotated with varimax rotation was used. From this extraction, I obtained one component. Table 4 presents the EFA results. All items indicated high factor loadings from 0.73 to 0.91 and the alpha coefficient was 0.83 . The cumulative variance of this one component in rotation sum of squared loadings is $68.7 \%$, of which the Eigenvalue is higher than 1. Average variance extracted (AVE) is 0.69 and it exceeded the threshold values 0.5 . Thus, Hypothesis 2 stating that the content of a relational strategy consists in the choices concerning (a) the way value is created and appropriated, (b) the partner, (c) the interorganizational dynamics, and (d) the way relations are established is confirmed.

Particular items correlate highly (Table 5), and all correlations are statistically significant $(\mathrm{p}<0.05)$. High means and medians for particular items also indicate that all strategic choices are linked and together they define the relational strategy of the firm.

To test Hypothesis 3, positing the dependence of the relational orientation of a firm and elements of the relational strategy that express its content, the correlations between these two constructs were calculated. Pearson's correlations were performed but taking into account the fact that the Likert scale is an ordinal scale (Miller and Salkind 2002), it is also necessary to use Kendall's tau factor. The results of these analyses are presented in Table 6.

Pearson's correlations are statistically significant $(\mathrm{p}<0.05)$, but moderately strong. Kendall's tau coefficient is statistically significant for the relationship between relational strategy and partners' expectations, and statistically insignificant for the relationship between relational strategy and partners of interorganizational relations. However, the obtained results allow confirmation of Hypothesis 3, which

Table 5 Descriptive statistics and correlations of relational strategy components

\begin{tabular}{llllllll}
\hline Variables of RO & $\bar{x}$ & $\mathrm{SD}$ & $\mathrm{M}$ & $\mathrm{IQR}$ & $\mathrm{SC} 1$ & $\mathrm{SC} 2$ & $\mathrm{SC} 3$ \\
\hline $\mathrm{SC} 1$ & 6.26 & 0.93 & 7 & 1 & & & \\
$\mathrm{SC} 2$ & 5.45 & 1.43 & 6 & 2 & $0.39^{*}$ & & \\
$\mathrm{SC} 3$ & 5.88 & 0.99 & 6 & 2 & $0.55^{*}$ & $0.56^{*}$ & \\
$\mathrm{SC} 4$ & 6.05 & 1.04 & 6 & 2 & $0.67^{*}$ & $0.59^{*}$ & $0.66^{*}$ \\
\hline
\end{tabular}

*Correlation is statistically significant for $p<0.05$

$\mathrm{R} \geq 0.39$ is essential with min. $\mathrm{p}<0.05$

$\bar{x}$ mean, $S D$ standard deviation, $M$ median, $I Q R$ interquartile range 
Table 6 Correlations between relational orientation and relational strategy of the firm

\begin{tabular}{lll}
\hline Relational orientation & Correlation coefficient & $\begin{array}{l}\text { Relational } \\
\text { strategy }\end{array}$ \\
\hline 'Partners of relations' (PR) & Pearson's r & $0.30^{*}$ \\
& Kendall's tau & 0.14 \\
'Partners' expectations' (PE) & Pearson's r & $0.37 *$ \\
& Kendall's tau & $0.23^{*}$ \\
\hline
\end{tabular}

*Correlation is statistically significant for $p<0.05$

means, that the stronger the relational orientation of the firm, the more the relational strategy is determined by the four strategic choices.

\section{Discussion and conclusion}

Competitive advantage for contemporary companies results more and more frequently from the ability to cooperate with others in order to obtain relational rent. This creates the need for research on firm's relational strategy, as this has not been clearly defined. The research results presented here made it possible to discern key strategic choices that make up the content of relational strategy. These, in the opinion of managers, should include choices regarding the process of creating and appropriating value, selecting a partner and their significance, and the associated interorganizational dynamics as well as the way of forming interorganizational relationships. This confirms the conceptual model proposed by Zakrzewska-Bielawska (2017) and provides the answer to the core research questions. The relational strategy is determined by a relational orientation, which is not a homogeneous construct, but consists of two components, namely, the number and variety of partners of relations and the expectations of partners, which should be included in the strategy of the firm. This is consistent with the findings of other researchers. For example, Lavie (2006) pointed out that relational orientation is related to formation and development of many various relations with individual partners on the one hand, and on the other it should take into account partners' needs. Ritala and Ellonen (2010) noted that clearly defined goals of cooperation and the meeting of reciprocal needs is the foundation of a relational orientation. Certainly, the relational orientation should be expressed in a firm's relational strategy.

Based on literature review, I had assumed that relational orientation depends on enterprise logic, but results of my research show that this is not true. No matter what the 'enterprise logic' is (transactional or relational), the relational orientation is relatively strong, which is expressed by the number and variety of interorganizational contacts made, the knowledge of partners' needs, taking them into consideration in a firm's strategy and taking action to satisfy them. This means that not only positivesum approaches (Post et al. 2002) that create benefits for firm and stakeholders and value creation approaches based on relational rents (Amit and Zott 2001) are related to relational orientation, but also those that concentrate on value capture (Lepak 
et al. 2007). Because there are no differences in the relational orientation of the firm depending on 'enterprise logic' as proposed by Crilly and Sloan (2012), a logic thus defined does not influence a company's relational orientation.

The main contribution of this paper includes both theoretical and practical aspects. From a theoretical perspective, the paper contributes to literature of strategic management by recognition of a firm's relational strategy and its elements. The managers studied indicate that interorganizational relations (especially with clients and suppliers) are very important to meet the company's goals and build its competitive advantage. From a practical perspective, the paper supplies guidelines regarding how to create the relational strategy of a firm by indication of the choices that should be made by managers to obtain benefits from it.

Limitations that result from the research methods used (subjectivity in the respondents' statements, differences in the level of answer detail or scope as well as extraneous comments in open-ended questions, a relatively small research sample size, limited to only medium-sized firms), may inspire further research conducted using more standardized tools on a representative sample that would allow the content of relational strategy to be described in a more objective way. Another interesting direction for scientific exploration may be proposing types of relational strategy based on identified strategic choices that make up its content.

Acknowledgements This research was funded by the National Science Centre in Poland (Grant number UMO-2015/17/B/HS4/00982).

Open Access This article is distributed under the terms of the Creative Commons Attribution 4.0 International License (http://creativecommons.org/licenses/by/4.0/), which permits unrestricted use, distribution, and reproduction in any medium, provided you give appropriate credit to the original author(s) and the source, provide a link to the Creative Commons license, and indicate if changes were made.

\section{References}

Ackermann, F., \& Eden, C. (2011). Strategic management of stakeholders: Theory and practice. Long Range Planning, 44(3), 179-196.

Amit, R., \& Zott, C. (2001). Value creation in e-business. Strategic Management Journal, 22(6-7), 493-520.

Arya, B., \& Lin, Z. (2007). Understanding collaboration outcomes from an extended resource-based view perspective: The roles of organizational characteristics, partner attributes, and network structures. Journal of Management, 33(5), 697-723.

Ashnai, B., Henneberg, S. C., Naudé, P., \& Francescucci, A. (2016). Inter-personal and inter-organizational trust in business relationships: An attitude-behavior-outcome model. Industrial Marketing Management, 52, 128-139.

Baraldi, E., Gressetvold, E., \& Harrison, D. (2012). Resource interaction in inter-organizational networks: Foundations, comparison, and a research agenda. Journal of Business Research, 65(2), 266-276.

Barney, J. B., \& Clark, D. N. (2007). Resource-based theory: Creating and sustaining competitive advantage. Oxford: Oxford University Press.

Barney, J. B., Ketchen, D. J., \& Wright, M. (2011). The Future of resource-based theory: Revitalization or decline? Journal of Management, 37(5), 1299-1315.

Baum, J. A. C., Cowan, R., \& Jonard, N. (2014). Does evidence of network effects on firm performance in pooled cross-section support prescriptions for network strategy? Strategic Management Journal, 35(5), 652-667. 
Bengtsson, M., \& Kock, S. (1999). Cooperation and competition in relationships between competitors in business networks. The Journal of Business \& Industrial Marketing, 14(3), 178-194.

Brandenburger, A.M., \& Nalebuff, B.J. (2011). Co-opetition. NewYork, USA: Crown Business, Currency/Doubleday.

Castaldo, S. (2007). Trust in market relationships. Cheltenham: Edward Elgar Publishing.

Child, J., Faulkner, D., \& Tallman, S. B. (2005). Cooperative strategy. Oxford: Oxford University Press.

Chin, W. W. (1998). The partial least squares approach to structural equation modeling. In G. A. Marcoulides (Ed.), Modern methods for business research (pp. 295-336). Mahwah, NJ: Lawrence Erlbaum Associates Inc.

Chin, K. S., Chan, B. L., \& Lam, P. K. (2008). Identifying and prioritizing critical success factors for coopetition strategy. Industrial Management \& Data Systems, 108(4), 437-454.

Coff, R. (2010). The coevolution of rent appropriation and capability development. Strategic Management Journal, 31(7), 711-733.

Contractor, F., \& Beldona, S. (2002). Interfirm learning in alliances and technology networks: An empirical study in the global pharmaceutical and chemical industries. In F. Contractor \& P. Lorange (Eds.), Competitive strategies and alliances. London: Elsevier Science.

Crilly, D., \& Sloan, P. (2012). Enterprise logic: explaining corporate attention to stakeholders from the 'inside-out'. Strategic Management Journal, 33(10), 1174-1193.

Danese, P., Romano, P., \& Vinelli, A. (2004). Managing business processes across supply networks: the role of coordination mechanisms. Journal of Purchasing and Supply Management, 10(4), 165-177.

De Wit, B., \& Meyer, R. (2005). Strategy synthesis: Resolving strategy paradoxes to create competitive advantage. Text and Readings. London: Thomas Learning.

Di Gregorio, D. (2013). Value creation and value appropriation: An integrative, multi-level framework. The Journal of Applied Business and Economics, 15(1), 39-53.

Donaldson, A., \& O’Toole, T. (2007). Strategic market relationships. New York: Wiley.

Doty, H., Glick, W., \& Huber, G. (1993). Fit, equifinality, and organizational effectiveness: A test of two configurational theories. Academy of Management Journal, 36(6), 1196-1250.

Dyer, J. H., \& Singh, H. (1998). The relational view: Cooperative strategy and sources of interorganizational competitive advantage. Academy of Management Review, 23(4), 660-679.

Eisenhardt, K. M., \& Martin, J. (2000). Dynamic capabilities: What are they? Strategic Management Journal, 21(10-11), 1105-1121.

Ellegaard, C., Medlin, C. J., \& Geersbro, J. (2014). Value appropriation in business exchange: Literature review and future research opportunities. Journal of Business \& Industrial Marketing, 29(3), 185-198.

Emden, Z., Calantone, R. J., \& Droge, C. (2006). Collaborating for new product development: selecting the partner with maximum potential to create value. Journal of Product Innovation Management, 23(4), 330-341.

Fawcett, A. M., Hofer, A. R., \& Fawcett, S. E. (2014). Relational strategies and firm performance: insights from an orienting conceptual framework. Journal of Business Logistics, 35(2), 151-152.

Feng, B., Fan, Z. P., \& Ma, J. (2010). A method for partner selection of codevelopment alliances using individual and collaborative utilities. International Journal of Production Economics, 124(1), $159-170$.

Fornell, C., \& Larcker, D. F. (1981). Evaluating structural equation models with unobservable variables and measurement error. Journal of Marketing Research, 18(1), 39-50.

Furrer, O., Thomas, H., \& Goussevskaia, A. (2008). The structure and evolution of the strategic management field: A content analysis of 26 years of strategic management research. International Journal of Management Reviews, 10(1), 1-23.

Gatignon, H., \& Xuereb, J. M. (1997). Strategic orientation of the firm and new product performance. Journal of Marketing Research, 34(1), 77-90.

Gefen, D., Straub, D. W., \& Boudreau, M. C. (2000). Structural equation modeling and regression: guidelines for research practice. Communications of the Association for Information Systems, 4(7), 1-70.

Grix, J. (2004). The foundations of research. London: Palgrave Macmillan.

Groves, R. M., Fowler, F. J., Couper, M. P., Lepkowski, J. M., Singer, E., \& Tourangeau, R. (2011). Survey methodology. New York: Wiley.

Guerras-Martín, L. Á., Madhok, A., \& Montoro-Sánchez, Á. (2014). The evolution of strategic management research: Recent trends and current directions. BRQ Business Research Quarterly, 17(2), 69-76.

Gulati, R. (1998). Alliances and networks. Strategic Management Journal, 19(4), 293-317. 
Gürtler, O. (2010). Haggling for rents, relational contracts, and the theory of the firm. Schmalenbach Business Review, 62(4), 359-377.

Haas, A., Snehota, I., \& Corsaro, D. (2012). Creating value in business relationships: The role of sales. Industrial Marketing Management, 41(1), 94-105.

Hammervoll, T. (2009). Value-creation logic in supply chain relationships. Journal of Business-to-Business Marketing, 16(3), 293-317.

Hardy, C., Phillips, N., \& Lawrence, T. B. (2003). Resources, knowledge and influence: The organizational effects of interorganizational collaboration. Journal of Management Studies, 40(2), 321-347.

Ho, J., Plewa, C., \& Lu, V. N. (2016). Examining strategic orientation complementarity using multiple regression analysis and fuzzy set QCA. Journal of Business Research, 69(6), 2199-2205.

Hoffmann, W. H. (2007). Strategies for managing a portfolio of alliances. Strategic Management Journal, 28(8), 827-856.

Hsieh, P., Lee, C., \& Ho, J. C. (2012). Strategy and process of value creation and appropriation in service clusters. Technovation, 32(7-8), 430-439.

Hsieh, H. F., \& Shannon, S. E. (2005). Three approaches to qualitative content analysis. Qualitative Health Research, 15(9), 1277-1288.

Iansiti, M., \& Levien, R. (2004). The keystone advantage: What the new dynamics of business ecosystems mean for strategy, innovation, and sustainability. Brighton: Harvard Business School Press.

Iyer, K. S., Srivastava, P., \& Rawwas, M. A. (2014). Aligning supply chain relational strategy with the market environment: Implications for operational performance. Journal of Marketing Theory \& Practice, 22(1), 53-72.

Jap, S. D. (2001). "Pie sharing" in complex collaboration contexts. Journal of Marketing Research, 38(1), 86-99.

Jiang, X., Jiang, F., Cai, X., \& Liu, H. (2015). How does trust affect alliance performance? The mediating role of resource sharing. Industrial Marketing Management, 45(1), 128-138.

Johnson, P., \& Duberley, J. (2000). Understanding management research: An introduction to epistemology. London: Sage.

Kobayashi, M. (2014). Relational view: Four prerequisites of competitive advantage. Annals of Business Administrative Science, 13, 77-90.

Lavie, D. (2006). The competitive advantage of interconnected firms: An extension of the resource based view. Academy of Management Review, 31(3), 638-658.

Lepak, D. P., Smith, K. G., \& Taylor, M. S. (2007). Value creation and value capture: a multilevel perspective. Academy of Management Review, 32(1), 180-194.

Li, L., Jiang, F., Pei, Y., \& Jiang, N. (2017). Entrepreneurial orientation and strategic alliance success: The contingency role of relational factors. Journal of Business Research, 72, 46-56.

Mariotti, F. (2012). Exploring interorganizational learning: A review of the literature and future directions. Knowledge \& Process Management, 19(4), 215-221.

Martínez-Sánchez, A., Vela-Jiménez, M. J., Pérez-Pérez, M., \& De-Luis-Carnicer, P. (2009). Inter-organizational cooperation and environmental change: Moderating effects between flexibility and innovation performance. British Journal of Management, 20(4), 537-561.

Miller, D. C., \& Salkind, N. J. (2002). Handbook of research design \& social measurement (6th ed.). Thousand Oaks: Sage Publications.

Mintzberg, H., Ahlstrand, B., \& Lampel, J. (2009). Strategy safari. Your complete guide through the wilds of strategic management. New Jersey: Prentice Hall.

Mintzberg, H., \& Waters, J. A. (1985). Of strategies, deliberate and emergent. Strategic Management Journal, 6(3), 257-272.

Moliterno, T. P., \& Mahony, D. M. (2011). Network theory of organization: A multilevel approach. Journal of Management, 37(2), 443-467.

Mu, J., Thomas, E., Peng, G., \& Di Benedetto, A. (2017). Strategic orientation and new product development performance: The role of networking capability and networking ability. Industrial Marketing Management, 64, 187-201.

Najafian, M., \& Colabi, A. M. (2014). Inter-organizational relationship and innovation: A review of literature. Global Business \& Management Research, 6(1), 52-70.

Panayides, P. M. (2007). The impact of organizational learning on relationship orientation, logistics service effectiveness and performance. Industrial Marketing Management, 36(1), 68-80.

Peppard, J., \& Rylander, A. (2006). From value chain to value network: Insights for mobile operators. European Management Journal, 24(2), 128-141. 
Podsakoff, P. M., Scott, B., MacKenzie, J.-Y. L., \& Podsakoff, N. P. (2003). Common method biases in behavioral research: A critical review of the literature and recommended remedies. Journal of Applied Psychology, 88(5), 879-903.

Porac, J. F., Thomas, H., \& Baden-Fuller, C. (1989). Competitive groups as cognitive communities: The case of Scottish knitwear manufacturers. Journal of Management Studies, 26(4), 397-416.

Porter, M. E., \& Kramer, M. R. (2006). Strategy and society: the link between competitive advantage and corporate social responsibility. Harvard Business Review, 84, 78-92.

Post, J. E., Preston, L. E., \& Sachs, S. (2002). Managing the extended enterprise: the new stakeholder view. California Management Review, 45(1), 6-28.

Ritala, P., \& Ellonen, H. (2010). Competitive advantage in interfirm cooperation: Old and new explanations. Competitiveness Review, 20(5), 367-383.

Ronda-Pupo, G. A., \& Guerras-Martin, L. Á. (2008). Dynamics of the evolution of the strategy concept 1962-2008: a co-word analysis. Strategic Management Journal, 33(2), 162-188.

Stabell, C. B., \& Fjeldstad, Ø. D. (1998). Configuring value for competitive advantage: On chains, shops, and networks. Strategic Management Journal, 19, 416-437.

STRATEGOR. (1997). Strategie, structure, decision, identite. Politique Générale D'entreprise. Paris: Dunod.

Tangpong, C., Michalisin, M., Traub, R., \& Melcher, A. (2015). A review of buyer-supplier relationship typologies: Progress, problems, and future directions. Journal of Business \& Industrial Marketing, 30(2), 153-170.

Thorgren, S., Wincent, J., \& Örtqvist, D. (2009). Designing interorganizational networks for innovation: An empirical examination of network configuration, formation and governance. Journal of Engineering and Technology Management, 26(3), 148-166.

Urbanowska-Sojkin, E. (2017). Wybory strategiczne w przedsiębiorstwach z perspektywy teorii strukturacji. Studia Oeconomica Posnaniensia, 5(9), 157-173.

Vargas-Hernández, J. G. (2014). Research methodology strategies in strategic management. Interdisciplinary Management Research, 10, 106-147.

Venkatraman, N., \& Subramaniam, M. (2002). Theorizing the future of strategy: Questions for shaping strategy research in the knowledge economy. In A. Pettigrew, H. Thomas, \& R. Whittington (Eds.), Handbook of strategy and management. Thousand Oaks: Sage Publications.

Vlaar, P. W., Van den Bosch, F. A., \& Volberda, H. W. (2007). On the evolution of trust, distrust, and formal coordination and control in interorganizational relationships toward an integrative framework. Group \& Organization Management, 32(4), 407-428.

Wagner, S., Eggert, A., \& Lindemann, E. (2010). Creating and appropriating value in collaborative relationship. Journal of Business Research, 63(8), 840-848.

Welch, M. (2006). Rethinking relationship. Management, exploring the dimension of trust. Journal of Communication Management, 10(2), 138-155.

Wong, J. M. (2011). A relational view of resources-based theory: The case of internationalization of Li \& Fung group. The Journal of Human Resource and Adult Learning, 7(2), 34-39.

Yang, H., Lin, Z., \& Peng, M. W. (2011). Behind acquisitions of alliance partners: Exploratory learning and network embeddedness. Academy of Management Journal, 54(5), 1069-1080.

Zakrzewska-Bielawska, A. (Ed.). (2014). Koopetycja $w$ rozwoju przedsiębiorstw high-tech. Determinanty i dynamika. Warszawa: Placet.

Zakrzewska-Bielawska, A. (2017). Seeking the content of the relational strategy: Conceptual framework. International Journal of Management and Applied Science, 3(4), 67-74. 